\title{
The Distributional Effects of Water Quantity Management Strategies: A Spatial Analysis
}

\author{
Joshua M. Duke, Robert W. Ehemann, and John Mackenzie*
}

\begin{abstract}
The distributional effects of three water policies are compared using spatial data from New Castle County, Delaware. The analysis reveals that a 591 percent increase in the marginal price of water achieves the same 25 percent reduction in consumption as rationing and mandatory restrictions. However, the distributional effects of pricing are distinct. Under rationing, households with low consumption must forgo essential uses. Mandatory restrictions are more equitable, shifting the conservation burden to residents living on larger parcels. With a threshold to protect essential consumption, the pricing policy places the burden of conservation on households with higher incomes and larger parcel sizes.
\end{abstract}

\section{INTRODUCTION}

Water supply managers in growing regions must address increasing demand for an essentially fixed, though highly variable, resource. Suburban growth broadly distributes the demand for water, increasing the need for infrastructure and raising challenges that are exacerbated in times of deficit. This paper investigates the relationships among the spatial distribution of a region's residential population, water deficits, and the response of residential water demand to three different deficit-management policies: (1) water-scarcity pricing above a threshold; (2) water rationing; and (3) mandatory water restrictions on outdoor use. The distributional effect of each policy is assessed using spatial data.

The first section of this paper reviews common demand-side management techniques, with particular attention given to incentives for conservation. In the second section, a model of residential water demand is adapted to the three deficit-management techniques. The third section describes the data collected on residential water consumption in northern New Castle County, Delaware. Results are then presented from the application in which the three management techniques achieve a 25 percent reduction in residential water consumption. A final section interprets the results.

\section{DEMAND-SIDE MANAGEMENT OF WATER QUANTITY}

Demand-side policies for deficit management may be distinguished by whether or not they use price to signal the relative scarcity of water. Nonprice approaches include voluntary conservation, mandatory conservation, feedback, home auditing, restrictions, rationing, and leak detection. Price-based approaches

*Authors are Assistant Professor, former undergraduate research assistant, and Associate Professor in the Department of Food and Resource Economics, University of Delaware. Funding from the Delaware Water Resources Council supported this research. We have benefited from the assistance of the Delaware Water Resources Agency. 
include water-scarcity pricing, water alerts, seasonal pricing, increasing block rates, and excessive-use charges.

\section{Nonpricing Approaches}

Voluntary conservation approaches are politically expedient because they do not force any person to alter his or her behavior. Often, these approaches rely on an ecological ethic; voluntary conservation approaches signal residents when it is necessary to conserve or provide education about conservation. In addition to general governmental calls for voluntary restrictions, other voluntary approaches include programs geared to help residential users better understand their water consumption behavior, such as feedback and home auditing. Aitken et al. (1994) established an experimental feedback program in Melbourne, Australia, in which three levels of information were given to residents about their personal water consumption: (1) no feedback; (2) feedback on personal water consumption; and (3) feedback on consumption, which was artificially reduced by 10 percent. Using a weekly postcard describing household water consumption and average consumption among similar households, Aitken et al. (1994) found that more frequent consumption information led to conservation. The experimental group receiving the artificially low similar-household information reduced its consumption more than the accurate feedback group (Aitken et al. 1994). Nelson (1992) examined a home auditing program in California aimed at single-family houses in the upper quartile of consumption that fixed leaks, replaced showerheads, added toilet tank displacement devices, and evaluated lawn irrigation practices. Nelson (1992) found that consumption decreased by 4.6 percent among program participants, but that only 21 percent of the reduction came from decreased outdoor uses.

Regional governments often turn to mandatory restrictions if voluntary conservation efforts fail. Ex ante restrictions implement water conservation measures prior to deficits, while ex post restrictions occur during deficits. For instance, Tucson, Arizona, offered incentives for participants in a residential desert landscaping program (Cuthbert 1989). Other types of ex ante restrictions include mandatory low-flow toilets and other conservation fixtures. Ex post restrictions are short-term solutions to deficits, which often limit outdoor consumption such as watering lawns and washing cars. Conservation gains from mandatory restrictions must be balanced against enforcement costs and costs associated with the indiscriminate manner in which the restrictions limit some important uses of water (for example, the loss of valuable landscaping plants).

Water rationing is perhaps the most severe conservation technique, though strict rationing of residential water is viewed as "politically unacceptable" (Renwick and Archibald 1998). During deficits, Kingston, Jamaica, has shut off water for several hours per day (Rosenberg 2000), while Sao Paulo, Brazil, has shut off water for one day for every two days it is provided (Lehman 2000). Rationing, like mandatory restrictions, achieves conservation targets without accounting for the value of various uses of water. As such, water may be allocated inefficiently under 
mandatory restrictions and rationing. Although some of the effectiveness of rationing is limited by behavioral adjustments-consumers increase water use when the water is on-rationing likely remains the most direct way to achieve conservation goals.

\section{Pricing Approaches}

Mechanisms for pricing water tend to vary with the quantity and quality of information provided to consumers and the technical capabilities of suppliers. An efficient pricing mechanism would allow the price of water to change instantaneously to reflect its relative scarcity (embodied by the marginal cost of supplying the water) and would ensure that consumers were aware of the price at all times. Although perfectly efficient pricing may be impractical, water managers may use price-based approaches in varying degrees to capture some of the efficiency gains associated with pricing.

Perhaps the most familiar price-based approach, the increasing block rate encourages conservation by raising the price for water as additional gallons are consumed. Pint (1999) assessed an increasing block rate used by California's Alameda County Water District, which increased price up to four times in the highest block on consumption over a bimonthly threshold averaging 350 gallons per day. Pint's (1999) results suggest the validity of using existing elasticity measures for large price changes. Under the new increasing block rate policy, Pint (1999) found that 78 percent of households had consumption below the daily threshold while only 57 percent consumed less than 350 gallons per day before the policy. Increasing block rates are mainly targeted toward areas with chronic deficit problems, yet several other price-based approaches are in use where deficits are sporadic.

Seasonal pricing raises price during periods of high use or low precipitation. Renzetti (1992) simulated seasonal pricing and found a 4 percent gain in the efficiency of water allocation. Indeed, Renwick and Green (2000) found that the responsiveness of households to changes in price increases by 25 percent during summer months. Other price-based approaches encourage conservation in a similar manner. Excess-use charges are imposed on residents who exceed specified levels of consumption or use water for nonpreferred uses. De facto impact fees on nonpreferred water uses occur, for instance, when a municipality charges a sewer use fee for all water supplied to each household. As such, water applied to lawns or indoor plants is essentially charged a higher fee than water that uses sewer services. More complex pricing schemes are also used. For instance, Tippett and O'Hare (1999) describe the City of Santa Fe's Water Emergency Ordinance, which formalized a series of restrictions that increase in severity with the percent deficit. Tippett and O'Hare (1999) reported that, during a deficit in 1996, mandatory restrictions on outdoor use were combined with goals and penalties, including 25 percent consumption reductions and a set of large surcharges on residential consumption above a monthly threshold averaging 200 gallons per day. As a result of 
these measures, "many" residential water bills surpassed $\$ 1,000$ per month and overall residential water use dropped by 28 percent (Tippett and O'Hare 1999, p. 171). High-consumptive users were especially responsive; households with average consumption over 403 gallons per day dropped to 9 percent in August 1996 from 25 percent in the previous year (Tippett and O'Hare 1999).

Studies focusing on scarcity pricing have been more rare since such policies are uncommon in the real world. The political aversion to scarcity pricing arises from concerns for income distribution (The Economist 1993; Collinge 1992; Renwick and Archibald 1998). Such aversion persists despite the availability of thresholds, subsidies, and other policy responses that could mitigate fairness concerns while improving the efficiency of allocating water. Collinge (1992) proposed a "discount coupon system" as a mechanism to achieve the efficiency gains of scarcity pricing without public officials having to raise water prices and then deal with the disposition of excess revenue. To our knowledge, the only paper to examine comprehensively the distributional effects of various demand-side management policies in times of deficit is Renwick and Archibald (1998). Renwick and Archibald (1998) collected panel data on household consumption under several conservation policies near Santa Barbara, California, during a prolonged deficit. Renwick and Archibald (1998) found that households on large parcels (0.55 acres and greater) had larger quantity reductions. Renwick and Archibald (1998) also found that low-income families are more responsive to price (elasticity of -0.53 ), whereas the upper-middle-income households were less responsive (elasticity of -0.22 ) and high-income households were the least responsive (elasticity of -0.11 ). The present paper follows this line of research on the performance of scarcity pricing vis-à-vis nonprice alternatives. Beyond contributing to the sparse literature on the distributional effects of pricing, a main contribution of this paper is to present the results of the policy simulations spatially via a GIS. The figures allow for the communication of a great deal of distributional data in a relatively compact form. This paper also differs somewhat in that deficit management is studied in an eastern U.S. metropolitan context (unlike most economic studies, which have focused on western municipalities).

\section{CONCEPTUAL MODEL}

Water is a special commodity, which endows suppliers with a higher standard of social responsibility, including objectives such as service reliability, quality, and production cost recovery. During droughts, conservation becomes an important tool in helping to meet reliability and cost recovery goals. Varying price to reflect relative scarcity penalizes excessive uses and rewards conservation efforts. It is generally appreciated that a politically established threshold should be used to protect essential consumption from price increases. A threshold, then, defines the institutional environment in which the cost-effective allocation of water is determined. Scarcity pricing above the threshold achieves that goal efficiently. 


\section{Modeling Water Demand}

The price elasticity of residential water demand is used to estimate how consumers change their water consumption in response to a change in price. A price elasticity of -0.25 means that a 1 percent increase in price will result in a 0.25 percent decrease in consumption. As price elasticity becomes more negative, residents are assumed to be more responsive to price changes. Elasticity is most accurate for small changes in price around its mean and the mean of quantity. In a meta-analysis of 124 elasticities from 24 journal articles, Espy, Espy, and Shaw (1997) found an average price elasticity of -0.51 . The present paper employs a flexible demand model reported in Opitz et al. (1998) and derived using the Institute for Water Resources Municipal And Industrial Needs software program. Opitz et al.'s (1998) model scales easily over space and time and explains residential water demand in terms of readily available data. Summer and winter versions of the Opitz et al. (1998) model are presented in Equations 1 and 2, respectively:

$$
\begin{aligned}
& \mathrm{q}_{\text {summer }}=\alpha_{\mathrm{s}} \mathrm{I}^{0.4} \mathrm{H}^{0.4} \mathrm{~L}^{-0.65} \mathrm{~T}^{1.5} \mathrm{R}^{-0.25} \mathrm{P}^{-0.25} \mathrm{e}^{-0.0005 \mathrm{~B}}, \\
& \mathrm{q}_{\text {winter }}=\alpha_{w} \mathrm{I}^{0.4} \mathrm{H}^{0.45} \mathrm{~L}^{-0.3} \mathrm{~T}^{0.45} \mathrm{R}^{-0.02} \mathrm{P}^{-0.04} \mathrm{e}^{-0.0005 \mathrm{~B}} .
\end{aligned}
$$

The quantity demanded, $q$, is the predicted average water consumption based on median household income (I); average number of people in a household (H); average housing density in units per acre (L); average maximum daily temperature (T); rainfall (R); marginal price of water, including sewer charges related to water use (P); and fixed charge or rate premium (B). The price elasticities used are relatively unresponsive when compared to those reported in the literature and, thus, the simulated results in this paper are conservative interpretations of behavior. These models allow for the derivation of a unique intercept for each supplier's service area, $\alpha$, and are manipulated for the analyses.

\section{Conservation Scenarios}

These models provide the basis for analyzing the three deficit-management scenarios using a GIS in ARCView constructed by the authors at the University of Delaware. The GIS analysis allows for the graphical depiction of spatial variation generated by the analyses, which would otherwise require lengthy tables to reveal effects of the model under the scenarios. All three scenarios are constructed to reduce summer consumption by 25 percent, thereby simulating conservation during a deficit.

The first scenario represents water-scarcity pricing during times of deficit. The conservation goal is achieved by increasing the suppliers' price of water on consumption above a threshold. Specifically, Equation 1 is modified to account for a 25 percent deficit, a threshold, and a factor, $\theta$, that increases price above a threshold:

$$
\begin{aligned}
.75\left(q_{c, \text { summer }}\right)= & \gamma\left(\alpha_{s} I^{0.4} \mathrm{H}^{0.4} \mathrm{~L}^{-0.65} \mathrm{~T}^{1.5} \mathrm{R}^{-0.25} \mathrm{P}^{-0.04} \mathrm{e}^{-0.0005 \mathrm{~B}}\right)+ \\
& (1-\gamma)\left(\alpha_{\mathrm{s}} \mathrm{I}^{0.4} \mathrm{H}^{0.4} \mathrm{~L}^{-0.65} \mathrm{~T}^{1.5} \mathrm{R}^{-0.25}(\theta \mathrm{P})^{-0.25} \mathrm{e}^{-0.0005 \mathrm{~B}}\right) .
\end{aligned}
$$


In Equation 3, $\gamma$ represents the proportion of consumption up to the threshold and $(1-\gamma)$ represents consumption above the threshold. For consumption under the threshold, the price remains the same as in nondeficit times. Using the GIS, the right-hand side of Equation 3 was applied to each block and solved iteratively for $\theta$ until a 25 percent countywide reduction in consumption occurred. The solution, based on the data described in the next section, is $\theta=6.91$, or a 591 percent increase in summer price on consumption above a threshold. In this scenario, the incentive to conserve varies directly and proportionately with increases in each household's water bill. Consumers are allowed to balance their private costs and benefits on the margin for nonessential water consumption to achieve reductions efficiently. The effectiveness of scarcity pricing should improve-and thus the required price increase falls-as consumers have better information. For instance, consumers benefit from more frequent data on their consumption and from more information to help them plan future consumption, such as improved predictions about when deficits might occur.

The second scenario, water rationing, achieves a 25 percent reduction by physically restricting water in every household. This scenario imposes no penalties on inefficient water uses and requires the same proportionate reduction from all households. Rationing raises concerns for fairness because urban households with mainly essential uses of water are forced to reduce consumption at the same rate as households in large-parcel growth areas that are reducing their nonessential uses. Utilities that use rationing repeatedly may need to increase the percentage reduction progressively over time as consumers respond by increasing their nondeficit water use in order to augment their deficit allocation.

The third scenario employs a mandatory restriction on outdoor uses to achieve a 25 percent countywide reduction. Mandatory restrictions on outdoor water use were actually implemented during the 1999 drought in New Castle County. To reproduce these restrictions in the analysis, the third scenario redistributes the entire conservation burden to households on parcels sized 0.10 acre and larger. The households on smaller parcels are unaffected. Households that bear the burden of reducing under mandatory restrictions tend to be located in the newer growth areas of the county and have the greatest consumption per capita. Thus, these households have the greatest potential to reduce nonessential uses.

These policies have distinct effects on suppliers' revenue and profitability in times of deficit. When infrastructure allows for water transfers and certain parts of a region have excess supply, utilities in deficit areas may purchase water from other regional suppliers at high prices. Such behavior mitigates the need to conserve water during deficits, but results in higher prices to consumers during the succeeding nondeficit quarter as suppliers seek cost recovery. Moreover, some utilities may seek higher rates following deficits because of shortfalls in total revenue. As conservation policies, rationing and mandatory restrictions may require such cost-recovery measures, which penalize all consumers during nondeficit periods regardless of their behavior during deficits. In contrast, water-scarcity 
pricing allows consumers to bear the full cost of their actions during deficits. The extra revenue generated under a scarcity-pricing scenario can either be used to enhance deficit supply or to reduce rates during nondeficit periods.

\section{DATA}

The 1999 drought in New Castle County, Delaware, provides an empirical setting to study the distributive effects of water conservation through scarcity pricing, rationing, and mandatory restrictions. Because it is a fast-growing county with persistent supply problems and because it relies mainly on surface water, New Castle County is heavily dependent on the hydrologic cycle. The drought occurred as a result of deficit rainfall between the fall of 1998 and September 1999. For example, a city in the county, Newark, received 29.39 inches of precipitation between 1 October 1998 and 31 July 1999, which was below the average of 34.41 inches (Leathers 2001). In the final quarter of 1998, Newark's precipitation was 5.2 inches, well below the average of 9.95 inches (Leathers 2001). The policy response focused on restrictions, and scarcity pricing was not used. Introduced 23 July 1999 , voluntary restrictions initially reduced consumption by 15 percent, but consumption returned to normal in a few days (Delaware Water Resources Agency et al. 1999). Mandatory restrictions were implemented on 5 August 1999 and remained in place until 8 September 1999. During mandatory restrictions, total consumption remained approximately 15 percent below normal (Delaware Water Resources Agency et al. 1999). The drought ended with Hurricane Floyd, which brought 9.5 inches of rain over four days in mid September (NOAA 1999).

Consumption data are drawn from the northern part of the county, where residents get their water from one of seven suppliers. The Delaware Water Resources Agency provided average daily consumption data for 1998, by month and by supplier. Average daily consumption data for the winter (January through March) and summer (July through September) quarters represent recent consumption during pre-drought, though dry, conditions. The residential share of the total demand for each supplier was computed using data from a previous study of water consumption in New Castle County and assuming that the difference between total summer and winter consumption is entirely attributable to residents (Hurd 1998).

Data are also collected to derive the intercept for each supplier's service area in Equations 1 and 2, and to explain consumption in the scenarios. The price and fixed charge variables for each supplier are compiled from the Delaware Water Resources Agency (2000). The income, household size, and housing density variables are measured using 1990 Census block group level data. The 1990 median income is adjusted by a factor of 1.47 to approximate 1998 incomes. Using the GIS, block group population data from the 1990 Census are combined with 1997 residential-parcel data from the New Castle County Land Use Department to proxy for household-level data. Parcels analyzed are from the northern part of the county, which consists of mainly residential, nonfarm parcels. There are 159,435 
parcels in the 348 block groups served by water suppliers. The 1997 parcel data and the Census data also determine the housing density variable. Average residential parcel-level data by block group are treated as the unit of analysis in the GIS.

Different weather data are used to explain actual consumption and to perform the analyses. In order to calculate the intercepts based on 1998 consumption, actual average maximum daily temperatures and rainfall data are derived from a simple average of readings from Newark and Wilmington (Leathers 2001). Newark and Wilmington capture the spatial extremes of the area of study. For the winter quarter, the average maximum daily temperature was 50.95 degrees Fahrenheit and rainfall was 12.875 inches (Leathers 2001). For the summer quarter, the average maximum daily temperature was 85.02 degrees Fahrenheit and rainfall was 6.14 inches (Leathers 2001). In addition, data on 40-year averages of Newark and Wilmington weather are also used in the analyses. The 40-year average temperature was 44.83 in the winter quarter and 83.13 in the summer quarter (WorldClimate 2001). The 40-year average rainfall was 9.7 inches in the winter and 11.7 inches in the summer (WorldClimate 2001).

\section{FIGURE 1}

Average Parcel Size by Block (acres)

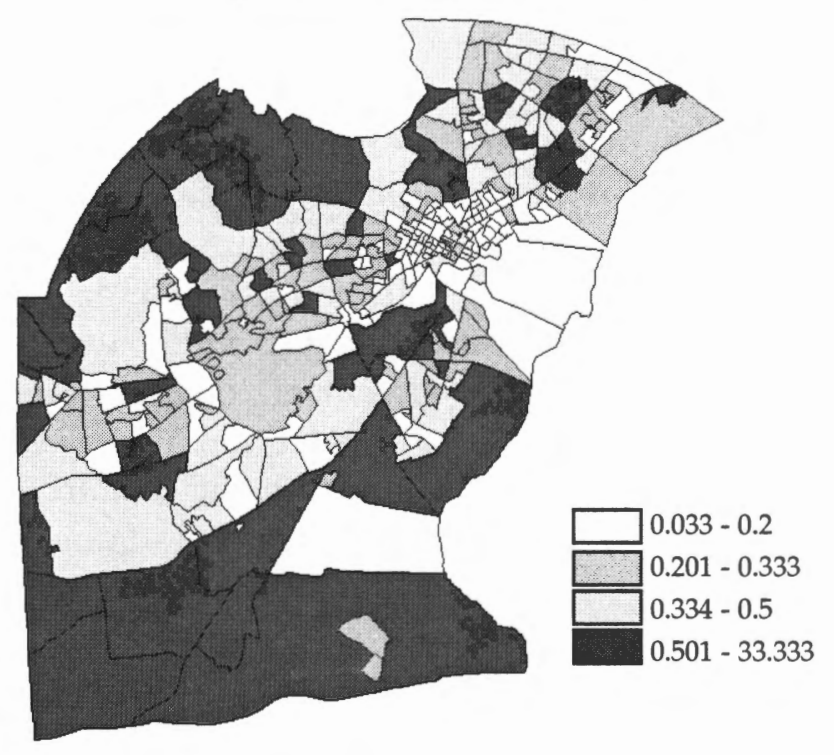

Each block group has unique values for median income, household size, and housing density and is assigned to one service area. At the supplier level, there are unique summer and winter values for price, fixed costs, and the intercept. The model is not sensitive to the relatively small variation in the weather data across the northern part of New Castle County, and so the same winter and summer weather values are assumed to apply to every water service area. Blockgroup statistics are presented for average parcel size (Figure 1) and median household income (Figure 2). The block groups with the largest average parcel sizes 
tend to be located in the northern and southern parts of Figure 1 and away from the Interstate 95 corridor, which runs from the middle part of the western border to the northeast. These block groups also tend to contain the newer residential growth areas, while the more established residential areas lie near Interstate 95.

\section{FIGURE 2}

Median Household Income by Block (dollars, 1998)

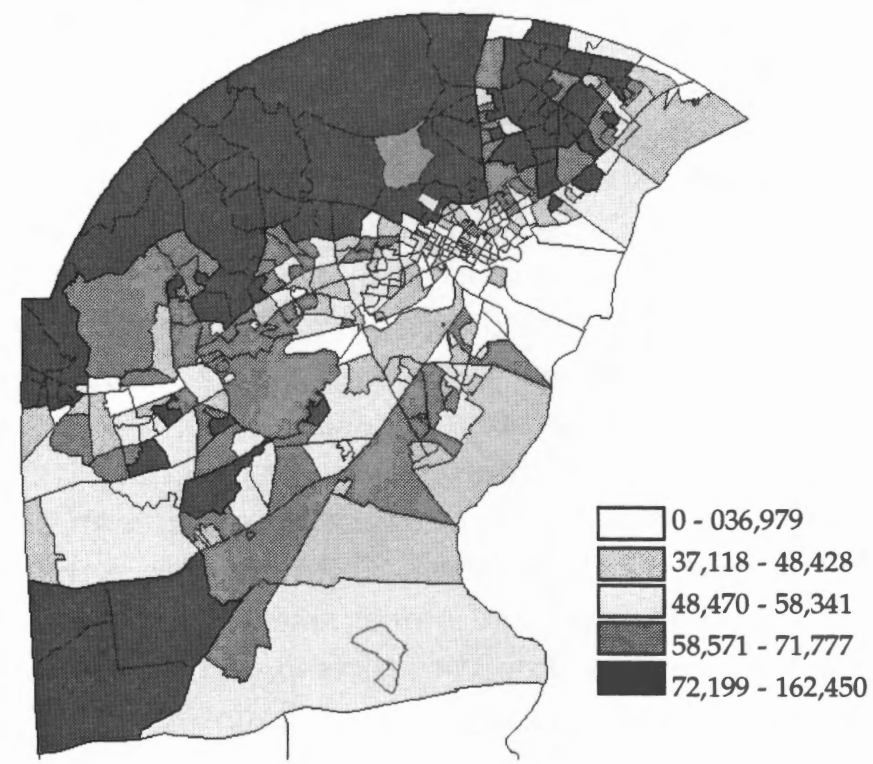

\section{RESULTS}

Equations 1 and 2 use actual consumption data to calibrate the intercepts, $\alpha_{\mathrm{s}}$ and $\alpha_{w}$ for summer and winter consumption in each service area (Table 2). The coefficients in Equations 1 and 2 and the intercepts explain, deterministically, average daily consumption by block group. Summary data are presented describing estimated water consumption by parcel size (Table 1) and by supplier (Table 2). Equations 1 and 2 establish baseline water consumption and expenditure data, which are presented spatially in Figure 3 (quantity) and Figure 4 (price).

\section{TABLE 1}

Block Average Consumption by Parcel Size

\begin{tabular}{|c|c|c|c|c|c|c|c|c|}
\hline \multirow[b]{2}{*}{$\begin{array}{l}\text { Average } \\
\text { Parcel Size } \\
\text { (acres) }\end{array}$} & \multicolumn{2}{|c|}{ Blocks } & \multicolumn{4}{|c|}{ Estimated Household Data } & \multicolumn{2}{|c|}{ Parcel Groupings } \\
\hline & Number & $\%$ & Number & $\%$ & $\begin{array}{c}\text { Median } \\
\text { Income } \\
(\$)\end{array}$ & $\begin{array}{l}\text { Summer } \\
\text { Water Use } \\
\text { (gallons/day) }\end{array}$ & $\begin{array}{l}\text { Summer } \\
\text { Water Use } \\
\text { (gallons/day) }\end{array}$ & $\%$ \\
\hline$<0.2$ & 132 & 37.9 & 61,288 & 38.4 & 39,456 & 140 & $8,580,465$ & 20.9 \\
\hline 0.2 to 0.3 & 81 & 23.3 & 31,631 & 19.8 & 57,217 & 225 & $7,109,648$ & 17.3 \\
\hline 0.3 to 0.4 & 42 & 12.1 & 20,600 & 12.9 & 66,501 & 296 & $6,093,688$ & 14.9 \\
\hline 0.4 to 0.5 & 38 & 10.9 & 22,334 & 14.0 & 68,638 & 314 & $7,017,922$ & 17.1 \\
\hline 0.5 to 0.6 & 16 & 4.6 & 4,740 & 3.0 & 72,337 & 435 & $2,063,773$ & 5.0 \\
\hline 0.6 to 0.7 & 12 & 3.4 & 5,637 & 3.5 & 81,552 & 433 & $2,442,651$ & 6.0 \\
\hline 0.7 to 0.8 & 4 & 1.1 & 3,509 & 2.2 & 86,960 & 559 & $1,962,079$ & 4.8 \\
\hline$>0.8$ & 23 & 6.6 & 9,695 & 6.1 & 72,471 & 590 & $5,720,705$ & 14.0 \\
\hline Total & 348 & & 159,434 & & 55,183 & 257 & $40,990,931$ & \\
\hline
\end{tabular}


TABLE 2

Block Average Consumption by Supplier

\begin{tabular}{|c|c|c|c|c|c|c|c|c|c|c|}
\hline \multirow[b]{2}{*}{ Supplier } & \multicolumn{2}{|c|}{ Blocks } & \multicolumn{3}{|c|}{ Households } & \multicolumn{5}{|c|}{ Supplier Level } \\
\hline & Number & $\%$ & Number & $\%$ & $\begin{array}{l}\text { Number } \\
\text { Per Acre }\end{array}$ & $\begin{array}{l}\text { Intercept } \\
\text { (Winter) }\end{array}$ & $\begin{array}{l}\text { Intercept } \\
\text { (Summer) }\end{array}$ & $\begin{array}{l}\text { Summer } \\
\text { Water Use } \\
\text { (gal/day) }\end{array}$ & $\%$ & $\begin{array}{c}\text { Ratio } \\
\text { Summer/ } \\
\text { Winter }\end{array}$ \\
\hline Artesian & 121 & 34.8 & 60,379 & 37.9 & 2.3 & 631.0822 & 19.43747 & $17,351,837$ & 42.3 & 1.32 \\
\hline Wilmington & 133 & 38.2 & 45,972 & 28.8 & 5.5 & 1094.73 & 36.2151 & $13,372,278$ & 32.6 & 1.185 \\
\hline United & 68 & 19.5 & 38,753 & 24.3 & 3.1 & 596.1727 & 14.90107 & $7,306,467$ & 17.8 & 1.02 \\
\hline Newark & 18 & 5.2 & 11,445 & 7.2 & 2.8 & 609.006 & 14.92203 & $2,435,694$ & 5.9 & 1.06 \\
\hline New Castle & 6 & 1.7 & 2,153 & 1.4 & 2.9 & 615.7689 & 15.01914 & $\begin{array}{l}2,450,631 \\
395,631\end{array}$ & 1.0 & 1.015 \\
\hline Del. City & 2 & 0.6 & 732 & 0.5 & 3.4 & 714.3107 & 15.41507 & 129,024 & 0.3 & 1.1 \\
\hline Total & 348 & & 159,434 & & 3.1 & & & $40,990,931$ & & \\
\hline
\end{tabular}

The results suggest that residential water consumption varies directly with residential parcel size. Parcel size tends to vary directly with median block-group income. Countywide comparisons of predicted "household" behavior are conducted by adjusting representative data from block groups by population. Households with median incomes below $\$ 30,000$ per year account for 6.8 percent of the population, but these households are responsible for only 3 percent of the summer water consumption. In contrast, households with median incomes greater than $\$ 100,000$ per year represent 4.8 percent of the population and are responsible for 14 percent of the summer consumption. The newer growth areas tend to have above average incomes and average parcel sizes of at least a quarter acre. One expects that parcel size and income vary directly with more expensive landscaping and swimming pools, which require more water during the summer months. The 15 percent of households with minimum half-acre parcels consume 30 percent of summer water. A comparison between summer and winter consumption (not shown graphically) found that 20 percent of households consume between 60 and 137 percent more during the summer. These high summer consumption block groups are located in the newer growth areas. The block groups with little variation in their seasonal usage tend to be located in the established urban areas near Interstate 95.

Figures 5 and 6 depict the scarcity-pricing scenario in which price increases by 591 percent during a three-month deficit. The threshold consumption is set at 48 gallons of water per day because it is the minimum estimated consumption observed in the study area. The results suggest that the burdens of quantity reduction and cost increases under scarcity pricing tend to fall in areas with larger parcel sizes and higher incomes. Established areas reduce consumption slightly and pay 100 to 200 percent more for water during the three-month deficit. The 30 percent of households that reduce daily consumption by more than 25 percent are responsible for 54 percent of the normal summer consumption. Also, the 30 percent of the households faced with more than a 200 percent increase in their quarterly bill consume 44 percent more water in the summer than in the winter. The new growth areas with larger parcels and higher incomes can expect at least a 200 percent increase in their bills during times of deficit, even after reducing consumption between 26 and 40 percent. 


\section{FIGURE 3}

Baseline Estimated Daily Summer Demand by Block (gallons per day)

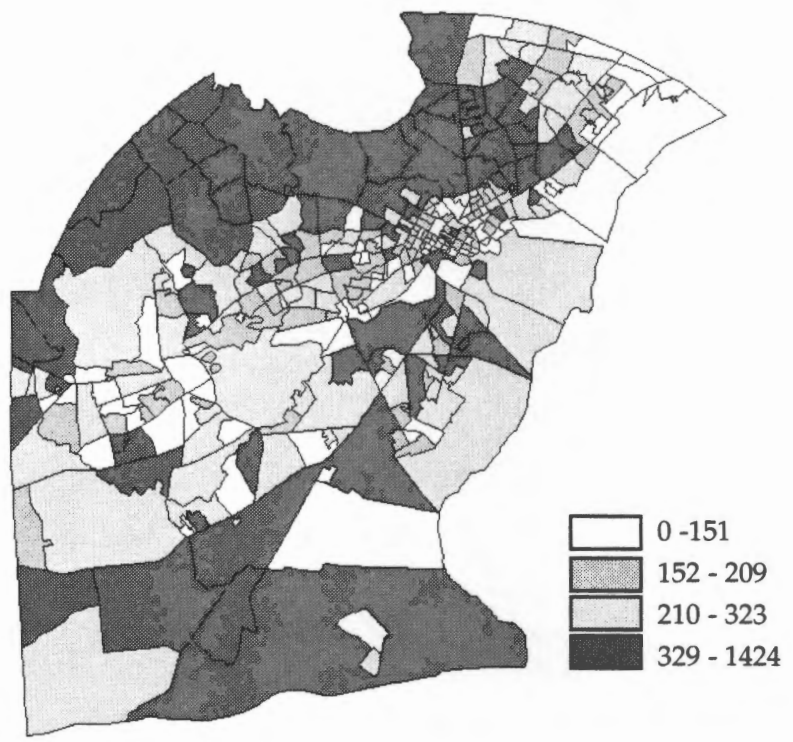

FIGURE 4

Baseline Estimated Summer Quarterly Bill by Block (dollars)

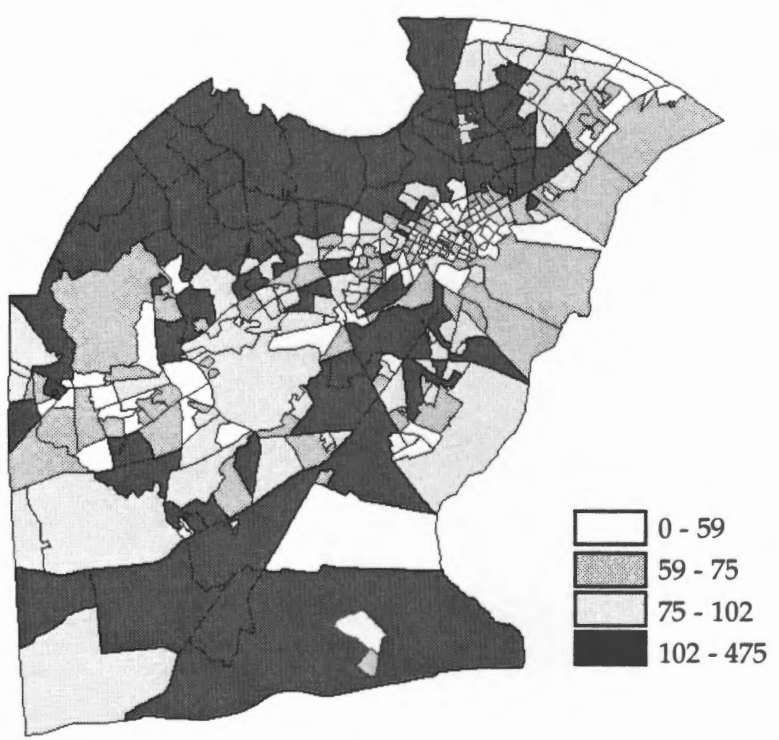


FIGURE 5

Scenario 1-Increase in Estimated Quarterly Bill by Block (percent)

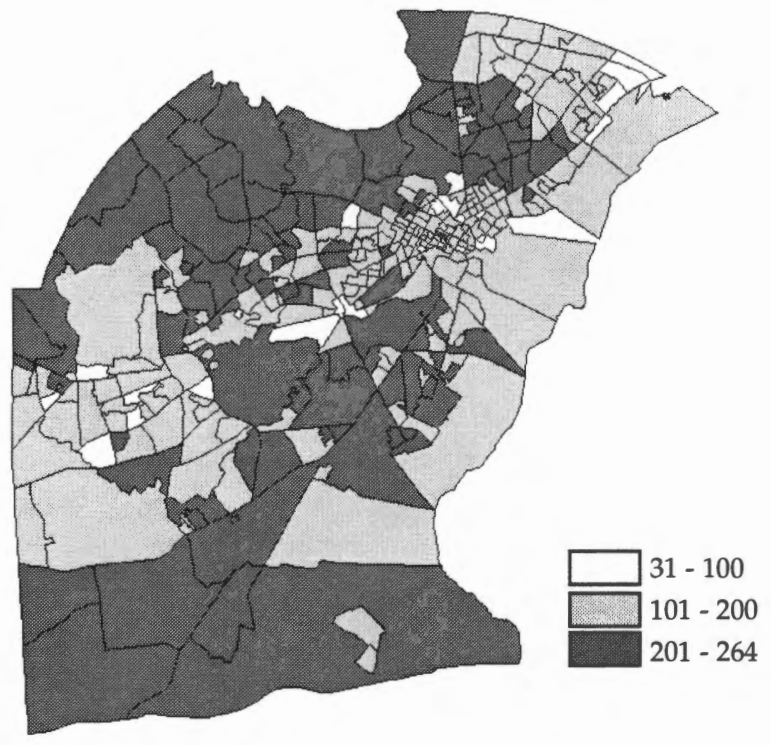

FIGURE 6

Scenario 1-Decrease in Quantity Demand by Block (percent)

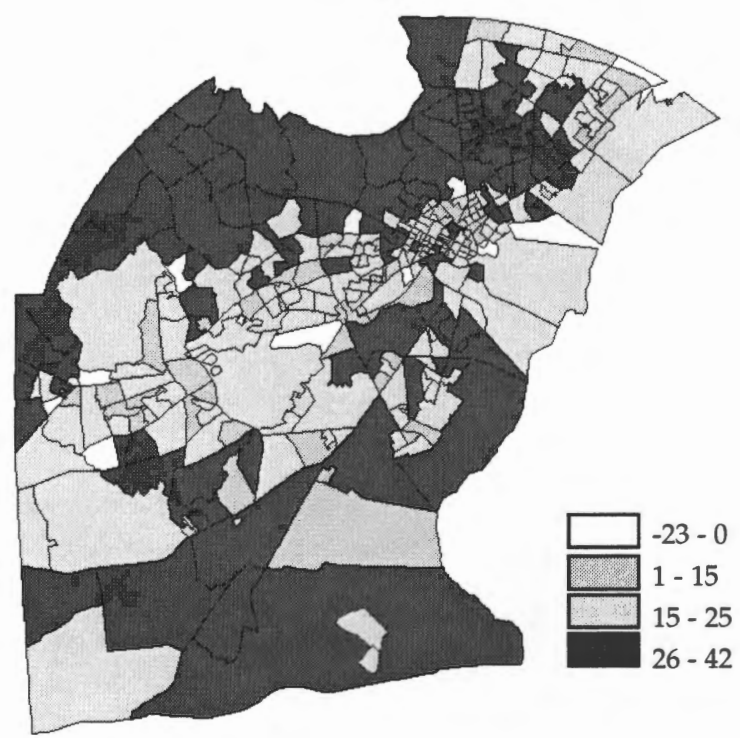


The water-rationing scenario in Figure 7 presents a sharing of water-deficit burden among households proportionate to nondeficit consumption. No quantityresponse figure is presented for this scenario because each block was responsible for a 25 percent reduction. Since price does not change, the burden occurs as unfulfilled demand. Shortages are mitigated during deficits by a lowering of consumers' bills, though when the deficit ends suppliers may seek to raise their rates for all users to recoup any losses. Under rationing, 16.6 percent of households have unfulfilled demand in excess of 100 gallons per day. These households consume 37.5 percent of the water in nondeficit periods and have median incomes averaging $\$ 84,721$. In contrast, 47 percent of households will face less than 50 gallons per day of unfulfilled demand. These households consume 24.7 percent of the water in nondeficit periods and have median incomes averaging $\$ 42,243$. Consumption responses to rationing also vary with housing density. The higherconsumptive group (over 100 gallons of unfulfilled demand) averages 1.4 households per acre, while the lower-consumptive group (less than 50 gallons of unfulfilled demand) averages 6.3 households per acre. This lower-consumptive group uses 9.5 percent more water in the summer than in the winter while the higherconsumptive group uses 54.7 percent more water in the summer.

\section{FIGURE 7}

Scenario 2-Decrease in Estimated Quarterly Bill by Block (percent)

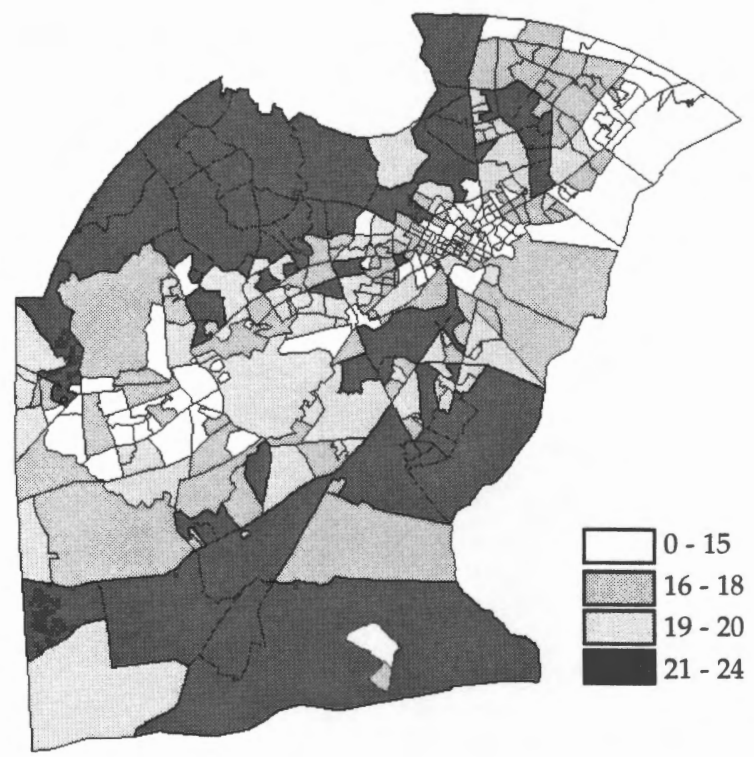

The mandatory restriction scenario illustrated in Figures 8 and 9 achieved a 25 percent reduction by targeting the 75 percent of households on parcels greater than 0.10 acre. Small-parcel households are concentrated in the urban areas and are unaffected by the policy during the deficit, so their consumption should not change. Households on larger parcels bear the entire burden of the deficit in the form of unfulfilled demand. Although the water bills of large-parcel households are reduced with restricted consumption, all consumers may face higher rates in 
the quarter following the deficit to meet the suppliers' cost-recovery needs. Under this policy, the 30.4 percent of households that consume 52.6 percent of water during deficits have per capita consumption greater than 100 gallons per day. These households have median incomes averaging $\$ 69,598$. In contrast, 40.3 percent of households have per capita consumption below 70 gallons per day and consume only 21.0 percent of the summer water. These lower-use households have median incomes averaging $\$ 43,361$.

\section{FIGURE 8}

Scenario 3-Decrease in Estimated Quarterly Bill by Block (percent)

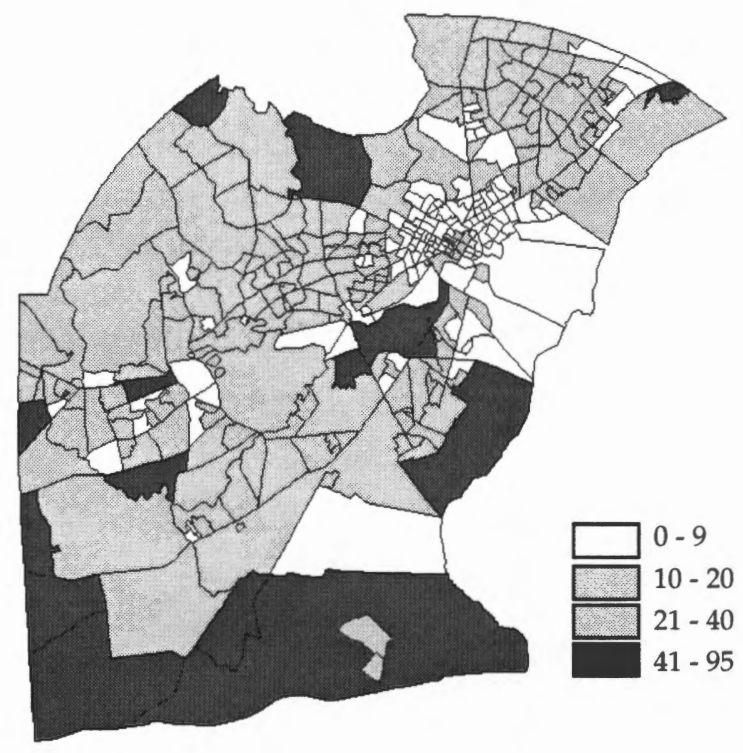

FIGURE 9

Scenario 3-Decrease in Quantity Demanded by Block (percent)

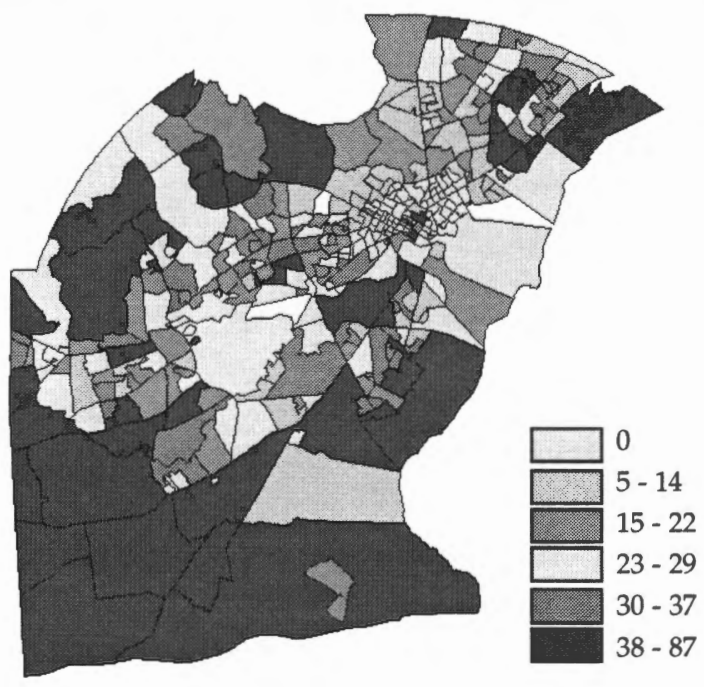




\section{DISCUSSION AND SUMMARY}

Water conservation policies are an important complement to supply-side solutions in deficit planning. The three conservation scenarios applied to data from New Castle County all produced the same effect-a 25 percent reduction in consumption. The application found that those households with the largest potential to conserve are located in the newer growth areas of the county, have higher summer demand, have relatively high incomes, and are located on relatively large parcels. The lower-consumptive households are located in established neighborhoods near Interstate 95 . These residents are characterized by lower-than-average incomes on smaller parcels. The distributional effects of these policies are quite distinct. Rationing seems to force households with lower consumption to forgo essential uses, while households with high consumption are able to conserve at the nonessential margin. Mandatory restrictions are more equitable in the treatment of low-consumptive households, but provide a rather blunt incentive for efficient consumption among high-consumptive households. Both rationing and mandatory restrictions may also result in cost recovery in the quarter following a deficit, which will raise rates for all consumers regardless of their behavior during the deficit. Scarcity pricing of water above a threshold increases rates for those who consume the most water during a deficit. The high-consumptive users tended to be in areas with higher incomes, while households in lower-income areas saw lower increases in their water bills. Scarcity pricing also allows all costs resulting from the deficit to be incurred, and in proportion to consumption, during the deficit.

The analysis demonstrated that a 591 percent increase in the price of water above a 48 -gallon threshold achieves the same 25 percent conservation goal as rationing and mandatory restrictions. Of course, implementation of water-scarcity pricing is problematic. Most consumers are unaware of the relationship between their water-consumption activities and the marginal contribution to their quarterly water bill. As suppliers and the government more accurately forecast deficits and explain consumption, the effectiveness of scarcity pricing would increase as consumers could make earlier, more efficient, decisions about conservation. Other policies also have implementation problems, though perhaps these are less challenging than those of water-scarcity pricing. Mandatory restrictions require enforcement, the costs of which are self-financing to some degree through the use of fines. Rationing may be the most direct way to address deficits. Yet the effectiveness of rationing is tempered as consumers overconsume when the "water is on" to hedge against times when the "water is off."

The principal contribution of this paper is the spatial representation of the distributional impacts of various water-management policies. It seems that a minimum requirement for equity is that essential water remain affordable during periods of deficit. Nonessential water should be priced, at the margin, to reflect its relative scarcity. The frequency and degree of price increases during deficits provide important financial information to suppliers and policy makers when deciding 
whether to seek temporary purchases of water from regional suppliers or to construct additional supply sources. Scarcity pricing above threshold consumption puts the conservation burden on the households that contribute the most to peak summer demands as well as immediately addressing the cost-recovery needs of suppliers. A political issue remains for the disposition of the additional revenue from scarcity pricing - no such issue is associated with rationing and mandatory restrictions. As such, water-scarcity pricing offers the flexibility of using additional revenue to lower rates during nondeficit periods.

\section{REFERENCES}

Aitken, Campbell K., Thomas A. McMahon, Alexander J. Wearing, and Brian L. Finlayson. "Residential Water Use: Predicting and Reducing Consumption." Journal of Applied Social Psychology 24 (2) (1994), 136-158.

Collinge, Robert A. "Revenue Neutral Water Conservation: Marginal Cost Pricing with Discount Coupons." Water Resources Research 28 (3) (1992), 617-622.

Cuthbert, Richard W. "Effectiveness of Conservation-Oriented Water Rates in Tucson." Journal American Water Works Association 81 (3) (1989), 65-73.

Delaware Water Resources Agency. Economic Synthesis of Water Rates in Delaware and Surrounding River Basins. Newark, Del.: Institute of Public Administration, University of Delaware, 2000.

Delaware Water Resources Agency, Delaware Geological Task Force, and Delaware Department of Natural Resources. The Final Report: Governor's Water Supply Task Force. 1999.

Economist, The. "Greenery and Poverty: Some Environmental Measures May Hurt the Poor more than the Rich." 18 September 1993, 80.

Espy, M., J. Espy, and W.D. Shaw. "Price Elasticity of Residential Demand for Water: A Meta-Analysis." Water Resource Research 33 (6) (1997), 1369-1374.

Hurd, Merna. Water Demand Trends \& Future Water Needs: New Castle County, Delaware. Dover: Delaware Department of Natural Resources and Environmental Control, 1998.

Leathers, Daniel J. "Delaware Climate Data." 2001 [cited 22 January 2002]. Web: (http://www.udel.edu/leathers/declim.html)

Lehman, Stan. "Sao Paolo Braces for Water Rationing." Associated Press 31 May 2000.

National Oceanic and Atmospheric Administration (NOAA). "Climate WatchSeptember 1999." December 171999 [cited 22 January 2002]. Web: (http://lwf.ncdc.noaa.gov/oa/climate/extremes/1999/september/extre mes0999.html)

Nelson, John Olaf. "Water Audit Encourages Residents to Reduce Consumption." Journal American Water Works Association 84 (10) (1992), 59-64. 
Optiz, Eva M., John F. Langowski, Benedykt Dziegielewski, Nancy A. HannaSomers, J. Scott Willett, and Richard J. Hauer. "Forecasting Urban Water Use: Models and Application." In Duane D. Baumann, John J. Boland, and W. Michael Hanemann, Urban Water Demand Management and Planning. New York: McGraw-Hill, 1998.

Pint, Ellen M. "Household Responses to Increased Water Rates during the California Drought." Land Economics 75 (2) (1999), 246-266.

Renwick, Mary E., and Sandra O. Archibald. "Demand Side Management Policies for Residential Water Use: Who Bears the Conservation Burden?" Land Economics 74 (3) (1998), 343-360.

Renwick, Mary E., and Richard D. Green. "Do Residential Water Demand Side Management Policies Measure Up? An Analysis of Eight California Water Agencies." Journal of Environmental Economics and Management 40 (2000), 37-55.

Renzetti, Steven. "Evaluating the Welfare Effects of Reforming Municipal Water Prices." Journal of Environmental Economics and Management 22 (1992), 147-163.

Rosenberg, Mathew J. "Jamaica to Limit Water Supply." Associated Press, 6 April 2000.

Tippett, Sherry J., and Craig O'Hare. "Using Price to Limit Water Use: A Case Study of the City of Santa Fe." Natural Resources Journal 39 (1) (1999), 169-173.

WorldClimate. Data on New Castle County, Delaware. 2001 [cited 21 January 2001]. Web: (http://www.worldclimate.com/cgi-bin/data.pl?ref=N39W075+2200+ 076410C) and (http://www.worldclimate.com/cgi-bin/data.pl?ref= N39W075+2200+1076410G2) 
